Historic, Archive Document

Do not assume content reflects current scientific knowledge, policies, or practices. 



\section{CATALOGUE AND PRICE LIST OF THE}

ALPHA NURSERY

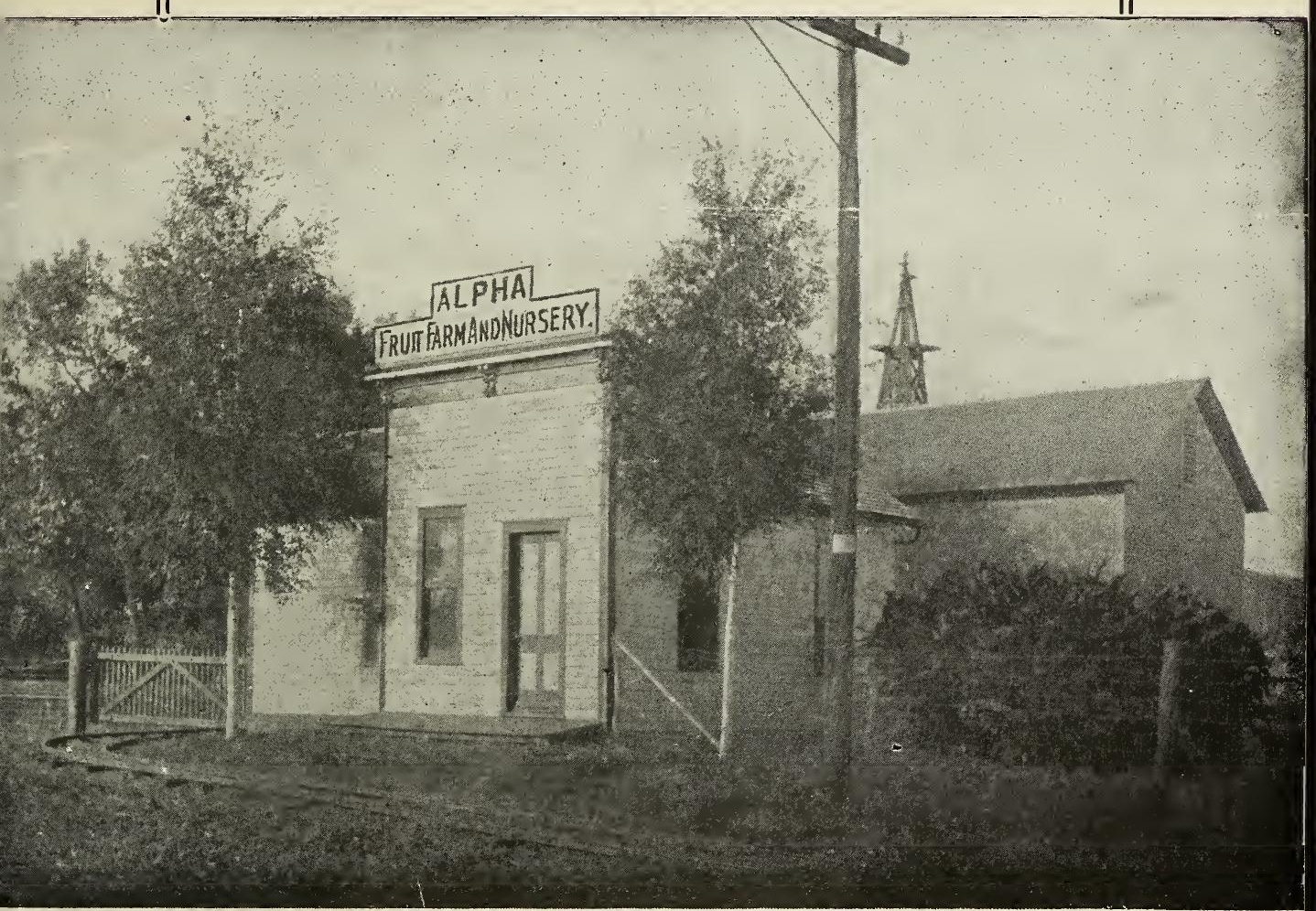

GEO. G. and H. G.s Wi IRT, Proprietors

\section{ALPHA, ILLINOIS}

Our aim is to grow only the very best, most hardy and productive varieties suitable to this climate

of fruit trees and plants in the very best possible manner 


\section{Introduction}

In order to introduce our Nursery and method of doing business to those who for the first time have received our catalogue, and who have never dealt with us, will say that we have been in the Nursery business for the past thirty years, of which we have been situated at Alpha for twenty years.

We ship to almost every state in the Union, and particularly to Henry, Mercer, Rock Island, Warren, Henderson, Knox, Hancock, McDonough, and Fulton counties, in Illinois.

A business conducted in one place for twenty years and having customers which for the past eight to ten years have sent in orders every year, is sufficient proof that our treatment of customers has been very satisfactory.

\section{LOCATION AND GROUNDS}

We are located about midway between Rock Island and Galesburg, and about midway between Galva and Burlington, on the C., B. \& Q. Thus we are able to ship in any direction, without going through the large railroad junctions, which cause much delay.

Our grounds are located opposite the depot at Alpha, our office and packing sheds are adjoining the railroad tracks, which makes it very convenient, and we can deliver stock to the trains without delay.

We have one of the largest and best arranged sheds in Northwestern Illinois, our storage shed has walls two feet thick, which makes it frost proof, this building will hold many car loads of Nursery stock. Surrounding this shed we have a large packing shed which we use in the spring to heal in our stock until it can be packed and shipped. The shed has electric lights and city water.

Our land is rich, black upland, well drained, and the best land that can be had for the growth of good, hardy, and healthy Nursery stock. We have used over thirty tons of lime stone dust on our land, which is the best fertilizer that we know of to produce a firm, healthy growth of trees, plants and shrubs.

\section{SHIPPING}

We have extra good shipping facilities, four local freight and eight express trains per day; we have a very low express rate, in many cases it is lower than the freight rates. We will ship all small packages by express. We recommend larger packages to be shipped by express, even if the cost is a trifle more than that of freight. This will insure immediate delivery. 


\section{General Information}

Orders should be sent in early. This will insure your order being filled when our stock is complete. We ship at the proper time of planting and notify the purchaser at the time of shipping.

If you cannot send cash with the order, send the order and remit or send good references before you wish the stock shipped.

FREIGHT - We will pay the ireight or express to your nearest railroad station on all orders of $\$ 5$ or over, east of Colorado, except on large shade trees.

CLUB ORDERS-If you do not wish $\$ 5.00$ worth, get your neighbors to club with you and we will tie and laks. each order separate and ship together and pay the freight or express.

TERMS-Cash or satisfactory reference from unknown parties before shipment. Known parties and parties sending satisfactory references, we will ship stock with the privilege of examining before payment.

PACKING-These prices are for stock well packed and delivered at the railroad station at Alpha.

MISTAKES cheerfully corrected, but no claims allowed unless made within seven days afer the stock is received.

WE WARRANT ALL STOCK TRUE TO NAME with the agreement that should any not prove true we will return the money paid for said stock, or replace with stock that is; but are not liable for damages other than herein named.

QUALITY-Our nursery stock is the very best that can be grown, and up to the standard in every way. We are entirely responsible; we own our nursery and farm, also other property.

RATES-Six at dozen rates, 50 at 100. Parties have the privilege of selecting as many varieties of any one kind of fruit or plants as they wish.

SHIPPING TIME-We commence making spring deliveries about the first week in April. Fall deliveries are started about the second week in October.

FALL PRICE LIST-We do not issue any. Save this list as these prices are good this fall.

PARCEL POST-Following are the rates on 1 to 100 plants, and this is to be added to the regular catalogue price when parties wish their stock to be sent by parcel post. These rates are for a radius of 150 miles, the first and second zones, for rates in the third zone add one-third to the following rates:

$$
\text { Number of Plants }
$$

Grapes

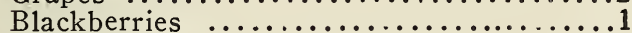

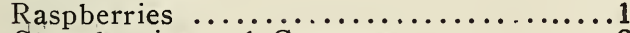

Gooseberries and Currants..............2

Asparagus .........................

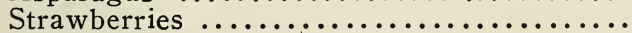

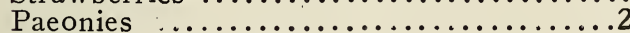

Shrubs (small size).................

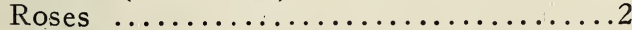

Climbing vines $\ldots \ldots \ldots \ldots \ldots \ldots \ldots \ldots 2$

Phlox

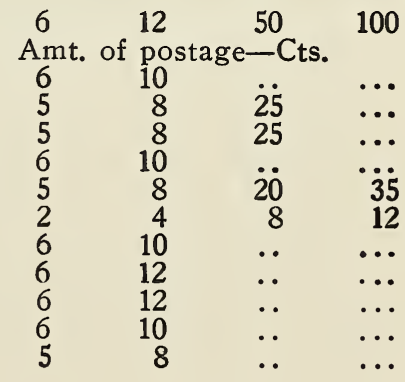




\section{APPLES}

4 to 6 feet. First class, No. 1, 25 cents each; 6 to 25,20 cents; 25 or more, 18 cents.

We can furnish 5 to $7 \mathrm{ft}$. heavy 3 -year trees of most varieties at $5 \mathrm{c}$ each more than the 4 to $6 \mathrm{ft}$. For resetting an orchard this size will give good satisfaction.

Three to $4 \mathrm{ft}$. Apples at 16 cents each; 6 to 25,14 cents each; 25 or more, 12 cents each, and 2 to $3 \mathrm{ft}$. Apples at 12 cents each; 6 to 25,10 cents each; 25 or more, 8 cents each. These trees are good, healthy, well-rooted stock, but we recommend the 4 to $6 \mathrm{ft}$. trees for general planting.

\section{SUMMER VARIETIES}

Benonia-Medium, roundish, pale yellow, shaded with crimson; juicy, tender, sub-acid. August.

Early Harvest-Medium to large, roundish, bright straw color, flesh white. July.

Astrachan Red-Large, roundish, nearly covered with crimson; juicy, sub-acid; tree strong, spreading grower. August.

Red June-Medium, oblong, hardy and productive; deep red color; flesh white, with tender, rich sub-acid. August.

Yellow Transparent-Medium, yellow, good quality, productive, excellent; bears early. July.

Liveland Raspberry-A very early variety of fine quality, good size, white striped and shaded crimson; a good healthy grower. very hardy.

\section{AUTUMN VARIETIES}

Bailies Sweet-Large dark red; tree a medium grower, very hardy October.

Dyer-Good size, pale yellow; very tender and juicy. Extra good quality. A good bearer; tree medium grower and hardy. October.

Duchess-Large size, roundish, streaked with red and yellow; flesh white, juicy, acid. September.

Famuese (Snow)-Medium, deep crimson; flesh snowy white, tender. November.

Golden Sweet-Fruit large, pale yellow; flesh tender, sweet and rich; hardy and a good grower. August and September.

Wealthy-Large, roundish, smooth, nearly covered with dark red; flesh white, fine, juicy, sub-acid, quality very good; good grower and productive. October.

Wolf River-Very large, redish striped; flesh coarse; tree very hardy and strong grower. October.

McIntosh Red-Fruit good size, red and of fine quality; tree a good, healthy grower; very hardy.

Aunt Hanna-Sweet, good size, light red, fine quality; very hardy and productive. November. 3 to $4 \mathrm{ft}$. $20 \mathrm{c}$.

\section{WINTER VARIETIES}

Ben Davis-Large, handsome, striped; good, hardy, vigorous and productive; late keepers, very showy. December to March.

Baldwin-Medium size, red; flesh yellow, sub-acid; tree a good grower, but a little tender here. December.

Black Ben Davis-Much like Gano in tree and fruit.

Domine-Medium size, greenish yellow, good quality. January.

Delicious-Fruit large, nearly covered with brilliant dark red, flesh fine grained, crisp and melting, juicy with a delightful aroma; of very highest quality. A splendid keeper and shipper. Tree hardy and a vigorous grower, with good foliage. A regular annual bearer. We were one of the 
first to introduce this variety and have a large stock of fine trees guaranteed true to name.

Gano-Good size, smooth and very attractive; deep red, resembles

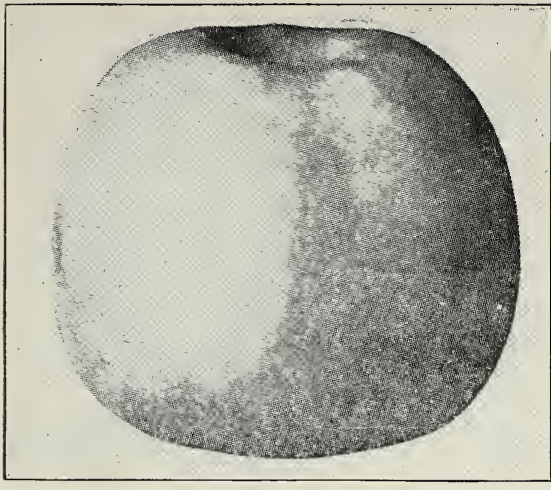

Grimea Golden Ben Davis, but is an improvement on that variety, being handsomer and better colored. December to March.

Grimes Golden Pippin-Medium, golden yellow, with white dots; crisp, tender and juicy, excellent; tree vigorous, hardy and productive. November and January.

Jenet-Small size, greenish ye1low; very late keeper.

Jonathan-Medium, red and yellow, very showy, juicy, excellent; tree slender and spreading; bears early. November to February.

King David-Medium size: dark red; tree hardy and a good grower. December.

Mammoth Black Twig-Large, deep red, sub-acid; early and abundant bearer, keeps well; tree a strong grower, resembles Winesap, but is superior in many ways; and fully one-third larger. January to April.

Northwestern Greening-Large, smooth, greenish yellow; flesh fine grained, firm; extremely hardy and a strong, handsome grower. December to April.

Paradise Sweet-Medium size, greenish yellow, sweet, good quality. December.

Roman Stem-Medium size, yellow, of good quality, very productive; tree a slow grower when young.

Russet-Medium size; flesh greenish white, good quality; tree a good grower and hardy. January.

Salome-Medium, yellow and red, very handsome; flesh whitish yellow, tender, slightly aromatic; tree hardy, vigorous, upright grower. January to May.

Seedless-Tree a good grower and hardy; fruit medium size, yellow, with red stripes.

Stayman's Winesap - F r u i r large, striped, nearly covered with red; flesh greenish yellow, very juicy and aromatic; very good; tree hardy and a strong, spreading grower; a good, early bearer; the best of our late winter apples. January to May.

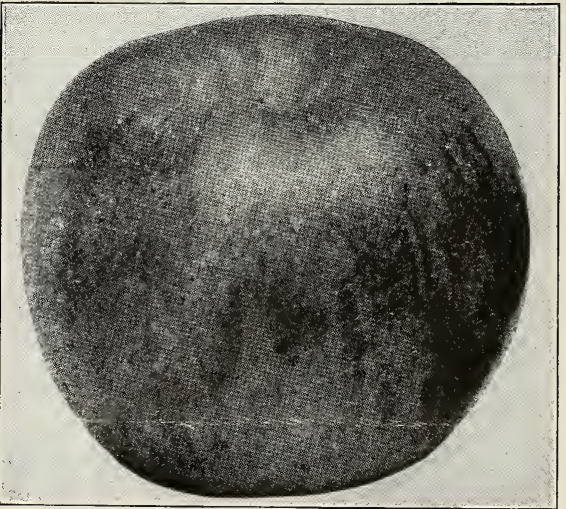

Stayman's Winesap

Tallman Sweet-Medium, pale yellow, firm, rich and very sweet; the most valuable, preserving and baking apple; vigorous. October and December.

Winter Banana-Fruit large, color clear yellow, overspread with pink; red-blushed; flesh yellow, very rich and juicy; tree a good grower; begins bearing very young. November to January.

Winesap-Medium, roundish, deep red, firm, crisp, juicy; excellent quality, moderate grower and good bearer; succeeds well throughout the West; very profitable. December to May. 
Winter Maiden Blush-Good size and of good quality. Tree a strong grower. January.

Yellow Bellflower-Large size, pale yellow; flesh white, sub-acid; tree a good grower; rather shy bearer. December.

We have a very large stock of extra fine apple trees and will make special prices on large orders.

\section{CHERRIFS}

4 to $6 \mathrm{ft}$., $35 \mathrm{c}$ each; 6 or more, 30c each; 3 to $4 \mathrm{ft}$., 25c each; 6 or more, $20 \mathrm{c}$ each

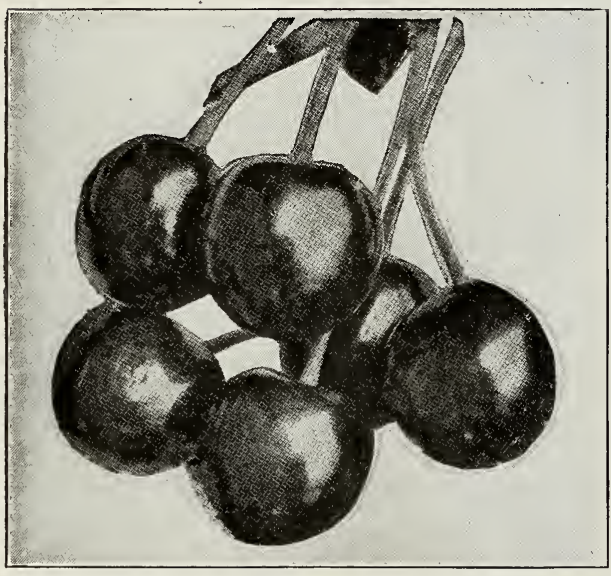

Cherries

Early Richmond-Medium, red, early, hardy, immensely productive; ripens last of June.

Large MontmorencyLarge; fruit beautiful dark red, sub-acid; of the very best quality; ten days later than the Early Richmond; a fine shaped tree; hardy and productive.

English Morello-Large, late, dark red fruit, very acid, tree a slow grower, not very hardy here.

Compass-Cross between a cherry and a plum. Fruit good size, bright red, sweet and juicy, of fine flavor. A good early bearing tree, perfectly hardy. 4 to $5 \mathrm{ft}$., $35 \mathrm{c}$ each.

Sweet Cherry-White with pink cheek; tree tall grower, hardy here, rather shy bearer. 2 to $3 \mathrm{ft} ., 25 \mathrm{c}$ each.

\section{PEACHES}

4 to $6 \mathrm{ft}$., 25 cents each; 6 to 25,20 cents; 25 or more, 18 cents

Alexander - Medium size, nearly round; skin greenish white, nearly covered with deep red; flesh white, juicy and sweet, adhering slightly to the stone. July 20 th.

Champion-Fruit large, del ic i o us, sweet, juicy, best quality of all early varties, skin creamy white, with red cheek; handsome, hardy and productive and a good shipper; adhering slightly to the stone. August 15th.

Crosby-Freestone, medium size, bright yellow, streaked with carmine; annual bearer; hardy. September 15 th.

Elberta-Freestone, very large, yellow, with red cheek, juicy and high flavored; flesh yellow; an excellent shipping variety. September 5th.

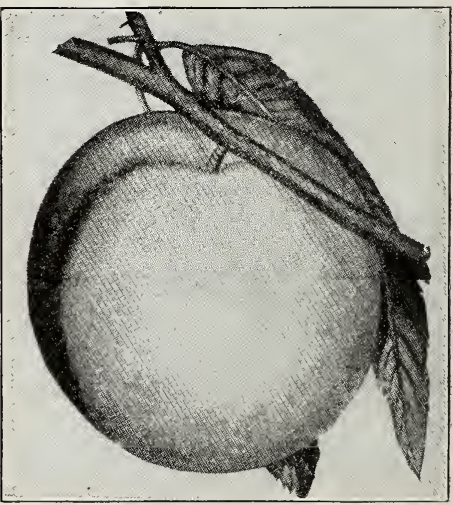

Champion Peach

Crawford's Early-Freestone, large yellow; flesh yellow, quality good; tree good grower, but the buds are tender. September. 
Crawford's Late-Freestone, very large, roundish, red cheek; flesh ye1low and rich; poor bearer here. October.

Lemon Cling-Very large, light yellow; flesh firm, yellow and rich; the great canning peach of the South and West. August.

Golden-Medium sized yellow freestone, of extra good quality, very hardy and prolific; not over 6 in one order. September 20.

\section{PEARS}

\section{4 to $6 \mathrm{ft}$., 35 cents; 6 or more, 30 cents each}

Bartlett-Large size, color rich yellow, with often a beautiful blush next the sun; buttery, very juicy, and highly flavored. September.

Duchess-Very large; dull, greenish yellow, streaked and spotted with russet; flesh white, buttery and very juicy, with a rich and very excellent flavor. October.

Keifer-A vigorous grower and an early bearer; very productive; fruit large, golden yellow, with red cheek. October.

Seckel-Medium; yellow, with crimson cheek; flesh melting sweet and aromatic; most exquisitely flavored pear known. Tree slow grower, but hardy and healthy. September.

Worden (Worden's Seckel)-Medium size; golden yellow, with russet cheek; flesh fine grained, juicy, buttery, with a rich aroma; recommended highly as a dessert and market sort. Tree hardy. September.

Dwarf Pears-Bartlett, Duchess and Seckel. These pears commence bearing much earlier than the standards.

Quinces-25 cents each; $\$ 2.50$ per

\section{PLUMS}

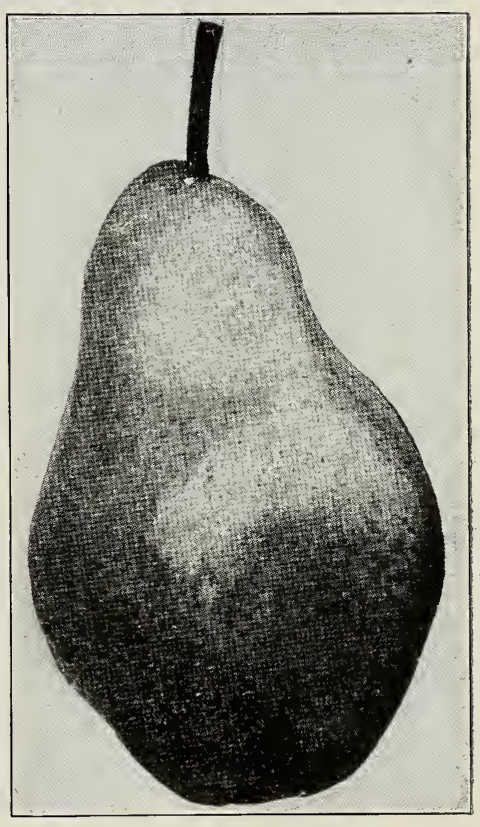

Keifer Pear

\section{4 to $6 \mathrm{ft}$., 35 cents each; 6 or more, 30 cents each}

Abundance-Medium size, showy, beautiful amber colored, turning to a rich cherry, highly perfumed, flesh light yellow, exceedingly juicy and tender. July.

Burbank-Very large, redish purple; flesh yellow and solid; cling, fine quality, one of the best for canning; tree strong, spreading grower, hardy and productive; subject to rot in wet years. August.

Wild Goose-Hardy, native, deep red with purplish bloom; flesh yellow, juicy and sweet; rapid grower, early and abundant bearer. July and August.

Blue Damson-Fruit small size, rather tart, good quality; dark purple, covered with a blue bloom; productive. September.

Yellow Egg-Fruit large, yellow, fair quality; fine for canning; tree a good grower and very productive; the best of the yellow plums for this climate. September.

Guii-Fruit large, purplish blue; flesh yellow, firm and sweet; freestone; tree hardy and a strong grower. It has done the best here of any of the large blue plums. September. 


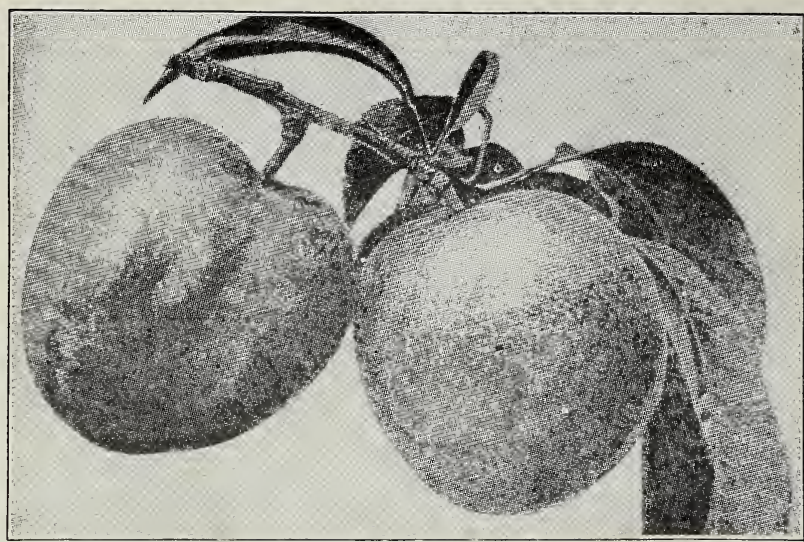

Red June Plum

Red June-A vigorous, hardy, upright, spreading tree; as productive as Abundance. Fruit medium to large, deep vermillion red with handsome bloom; very showy; flesh light lemon color, slightly sub-acid, of good and pleasant quality; pit small. Early.

Green Gage-Medium sized yellow freestone, of extra good quality; tree a slow dwarfish grower. August.

Chas. Downing-Large, round, red, very solid, and of extra good quality; hardy and productive. 3 to $4 \mathrm{ft}$. trees only.

\section{CRAB APPLES}

\section{5 cents each}

Hyslop-Dark Crimson, with bloom; very showy and popular.

Transcendant-Large, yellow striped with red.

\section{GRAPES}

Strong, healthy two-year vines, 10 cents each; $\$ 1.00$ per 12 Concord, $\$ 5.00$ per 100 ; Campbell's Early, $\$ 7.00$ per 100 ; other varieties, $\$ 6.00$

Campbell's Early-A strong grower, hardy and very early; an abundant bearer; bunches and berries very large, glossy black color; pulp sweet and juicy, with few seeds; ripens with the Moore's Early, but will hang on the vines until frost. We have kept them in baskets in fine condition until December.

Moore's Early-Black, bunches medium size and very compact; berries large and of excellent quality; ripens ten days before Concord, which makes it very desirable for market; very hardy, well suited for the North; one of the best.

Concord-Black, the most popular grape in America; bunches and berries large, hardy, healthy and productive.

Agawam-Red or maroon color; berries large, of rich, peculiar aromatic flavor; ripens a week later than Concord; vine a strong, rank grower.

Moore's Diamond-White, bunches and berries large; flesh tender, juicy, hardy, productive, early; fine quality.

Niagara-Bunch and berries large, greenish white changing to pale yellow when fully ripe. Quality fair. A little tender here, but hardy farther south. 


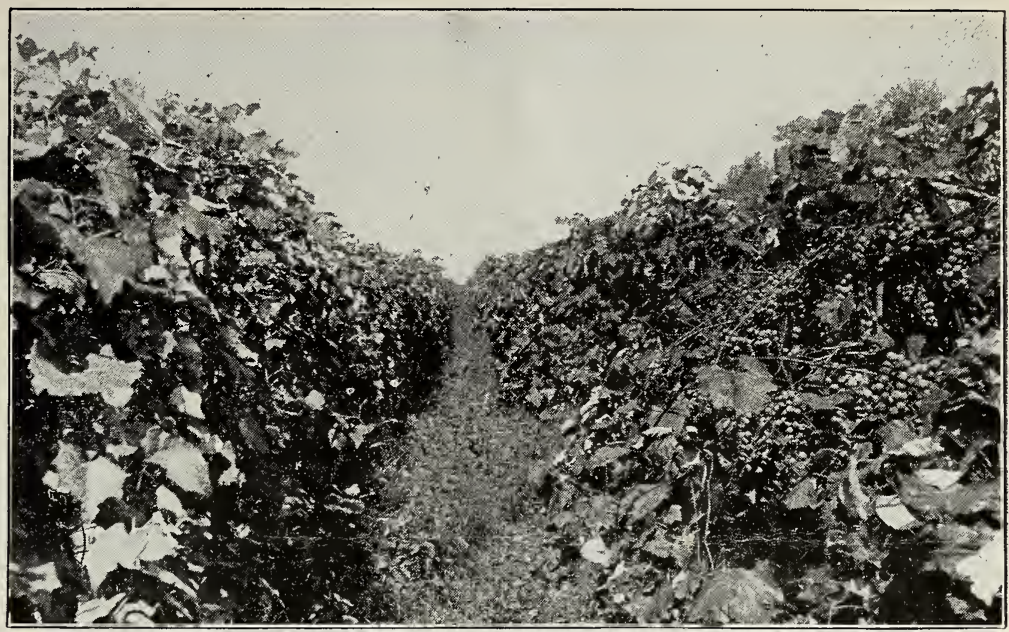

Grapes

Wyoming Red-Vine very hardy, healthy and robust; flesh tender, juicy and sweet; bunches and berries medium sized. The best of the red grapes for this climate.

We have a small stock of the following varieties at ten cents each: Lindy Red, Woodruff Red, Pocklington White, Eaton Black, Green Mountain White, Brighton Red, Delaware Red.

\section{STRAWBERRIES}

Senator Dunlap, 25 plants, 25 cents; 50 plants, 35 cents; 60 cents per 100; $\$ 2.50$ per $500 ; \$ 4.00$ per 1,000

Norwood, Gandy, Glen Mary, Brandywine, August Luther, 30 cents per 25; 40 cents per $50 ; 75$ cents per 100

For strawberry plants in the fall, add one-third to these prices. They should be planted between Aug. 20 and Sept. 20.

The following varieties of strawberries are all perfect flowering; that is, they do not need any other variety planted near them for fertilizer. We tie all strawberries 25 in a bunch, except the Everbearing. If the plants are to be sent by mail, see parcel post rates, page 1 .

Gandy-Extra large and handsome, firm, high quality; the very latest; most all of the crop ripens after the Dunlap.

Glen Mary-A large berry of good quality; deep red all the way through; a sweet, rich flavor; the plants are vigorous and productive.

Brandywine-A large, late berry, with strong, healthy foliage; first berries very large, balance small.

August Luther-An extra large berry, of good quality; a strong grower and productive.

Norwood-Extra large and of very fine quality; bright red all the way through, a strong, healthy grower; the best of the large fancy berries.

Senator Dunlap-Fruit good size, regular form, beautiful bright red; glossy, firm, splendid keeper and shipper; excellent quality; one of the best for canning; ripens early and continues a long time. We consider the Dunlap the best berry that grows. It and the Gandy will cover the season from early to late. 
Everbearing Strawberries-This kind of strawberries have proved a success. They are hardy and healthy, make a fair crop in June and another in the fall. The fall crop has been the best here and one that would pay well commercially.

Plant them the same as other varieties, cut off the blossoms up to July the first, and they will make a fair crop the first year. As soon as the berries begin to ripen put a fine mulch around the plants and keep them cultivated the second year. After the June crop take off the mulch and give them a good dressing of fine manure, cultivate well, then mulch heavy between the rows and close around the plants. All the varieties we offer have perfect flowers, but we find that the berries are more perfect when two varieties are planted together.

Americus-Berries fair size, bright red and extra good quality. Plant a healthy, strong grower, but makes very few plants. The fall crop of this variety has been very good here. Forty cents per $12 ; 70 \mathrm{c}$ per $25 ; \$ 1.80$ per 100 .

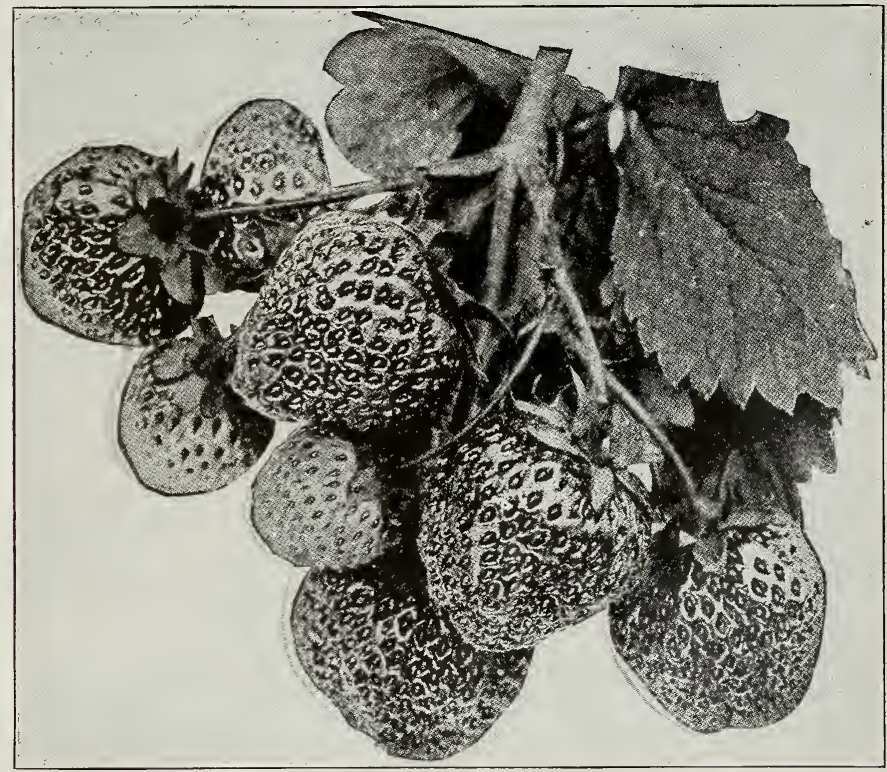

Dunlap Strawberry

Progressive-Berries, large, firm, and good quality; plant a healthy, strong grower and a good plant maker. This plant seems to be a general favorite. With us the June crop was better than the Americus, but the late fall crop not so good. This berry and the Americus are the best for this locality. Thirty-five cents per $12 ; 60$ c per $25 ; \$ 1.50$ per 100 .

Superb, Francis, Iowa and Productive-These are recommended to be good in certain localities. Twelve plants, 35c; 25 plants, 60 c.

\section{DEWBERRIES}

Lucretia-A trailing blackberry, larger and juicier than blackberries. Fruit ripens ten days before blackberries. For the best success, cover them in the fall like strawberries; in the spring take the mulching off and put it under them to keep the berries off the ground, and shorten the runners to eighteen inches. Prices: $35 \mathrm{c}$ per $12 ; \$ 2.00$ per 100 . 


\section{BLACKBERRIES}

Eldorado-Among the good points of this valuable new blackberry are great productiveness, hardiness, extra fine quality, and sweetness of flavor, without core, the berries are large, jet black, borne in clusters and ripen well together; sweet, melting, rich and pleasant to the taste. Price, $35 \mathrm{c}$ per dozen; $\$ 2.00$ per $100 ; \$ 15$ per 1,000 .

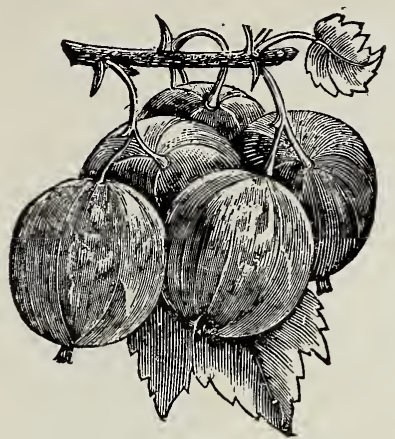

Champion

\section{GOOSEBERRIES}

Champion-A new variety introduced from Oregon, where it originated. Bush a strong, upright grower, very hardy and enormously productive; fruit round, entirely free from mildew and easily gathered. We consider this the best of the gooseberries for general planting. Strong two-year plants, $15 \mathrm{c}$ each; \$1.50 per 12 .

\section{RASPBERRIES}

35 cents per $12 ; \$ 1.50$ per $100 ; \$ 12.00$ per 1,000

Cumberland-One of the largest black raspberries known; has been well tested in nearly all sections, giving thorough satisfaction; in hardiness and productiveness it is unexcelled; the quality is the very best; the fruit is firm and will stand long shipments. It commences to ripen in mid-season and continues a long time; the bush is healthy and vigorous.

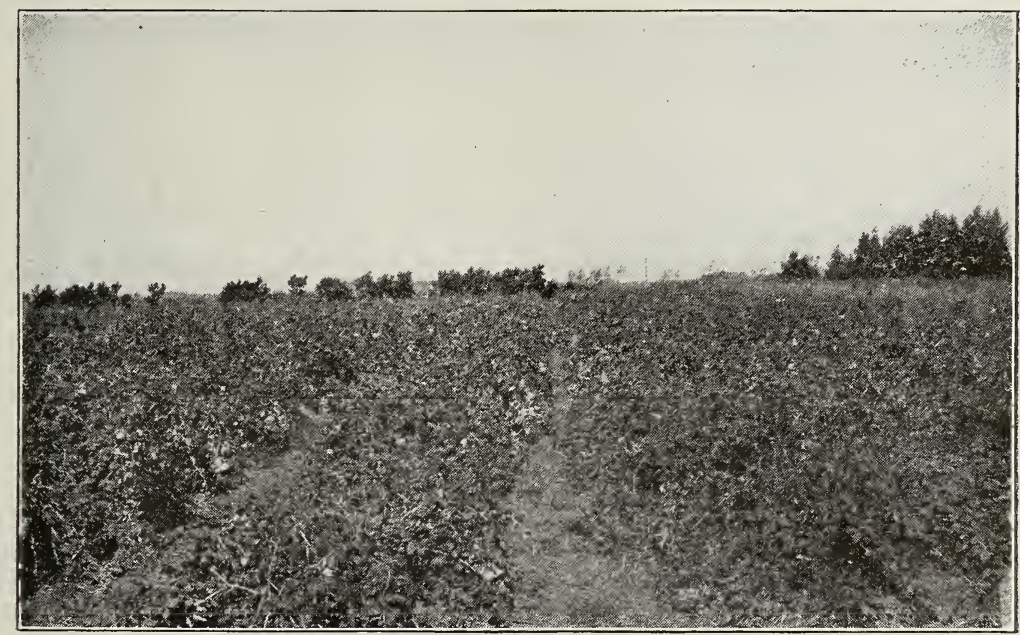

Cumberland Raspberries

Plum Farmer-Black, strong, healthy grower; berries large and firm, ripens earlier than the Cumberland and ripens its fruit in a very short time. A good market variety. 
Columbian-Deep, purpleish red and highly flavored, extra strong canes, wonderfully productive; berry large. Does not sprout. \$2.00 per 100 .

Cuthbert-Red, strong grower; fruit large and firm. The best of the reds for light soil. Sprouts.

Louden Red-Large size, very firm and hardy, moderate grower, the best of the reds for heavy, rich soil. Sprouts.

St. Regis (Everbearer)-Very early, fruit large and extra quality, good stocky grower and hardy. It is very much like the Louden except it makes a fall crop on the new canes. Thirty-five cents per $12 ; \$ 2.00$ per 100 ; $\$ 15.00$ per 1,000 .

\section{CURRANTS}

\section{Large two year, 10 cents each; $\$ 1.00$ per 12}

Pomona-Fruit clear, bright red, almost transparent; has but few small seeds; hangs on a long time after ripe; vigorous, healthy, hardy, most productive; quality best; good shipper.

Cherry-The largest of the red currants, strong, stocky bush; hardy, and moderate productive.

Black English-Largest and best of the blacks.

White-A good grower; berries yellowish white, sweet and mild.

\section{CHESTNUTS}

Paragon (Sobers)-The most widely planted and most uniformly successful variety yet cultivated in the United States. The three or more broad, thick, handsome nuts in each burr are of extra large size and quality. The tree makes a strong growth, bears early and abundantly, often bearing the second year from graft. Trees four years old, from graft, have produced one bushel each. They have borne here the second year. Four to 5 $\mathrm{ft}$. trees, $\$ 1.00$ each; 5 to $6 \mathrm{ft}$. well balanced, heavy trees, $\$ 1.50$ each.

American Sweet-The nuts of this tree form quite an item in our commerce. They are sweet and delicately flavored. This chestnut is also a grand timber and ornamental shade tree. Four to $5 \mathrm{ft}$., $35 \mathrm{c}$ each.

Apricots (Russian) -4 to $6 \mathrm{ft} ., 25 \mathrm{c}$ each.

Mulberries (Russian)-4 to $6 \mathrm{ft}$., 25c each.

Persimmons-3 to $4 \mathrm{ft}$., $25 \mathrm{c}$ each.

PIE PLANT-Linnaeus-Large, early, tender and fine, the very best of all. Large two year old roots, $10 \mathrm{c}$ each; $\$ 1.00$ per 12 ; good one year roots, $\$ 5.00$ per 100 .

ASPARAGUS-Conover's Colossal-Produces large, tender shoots of vigorous growth. None better. 25c per $12 ; \$ 1.00$ per $100 ; \$ 3.00$ per 500 .

HORSE RADISH-10c each; 50c per 12.

\section{EVERGREENS}

Arbor Vitae-The best for hedges. 18 to 24 inches, $25 \mathrm{c}$ each; 12 to 18 inches, 10c each, any number.

Norway Spruce-The best for windbreaks; 2 to $3 \mathrm{ft}$., $35 \mathrm{c}$ each; $\$ 3.00$ per dozen; 18 to 24 inches, $25 \mathrm{c}$ each; $\$ 2.40$ per $12 ; 12$ to 18 inches. $10 \mathrm{c}$ each, any number.

White Pine-2 to $3 \mathrm{ft} ., 35 \mathrm{c} ; 18$ to 24 inch, $25 \mathrm{c}$.

White Spruce-2 to $3 \mathrm{ft}$., $50 \mathrm{c}$ each.

Balsom of Fir-2 to $3 \mathrm{ft}$., $35 \mathrm{c}$ each; 18 to 24 inches, $25 \mathrm{c}$ each.

Black Hill Spruce-18 to 24 inches, $50 \mathrm{c}$ each.

Kosters Blue Spruce-18 to 24 inches, $\$ 2.00$ each.

Red Cedar-2 ft., 35c; $\$ 3.00$ per 12 . 


\section{ORNAMENTAI, TREES}

Popular Carolina-One of the most rapid growing trees, with large, deep green leaves; succeeds everywhere, especially adapted to cities, where it makes a fast growth, and resists

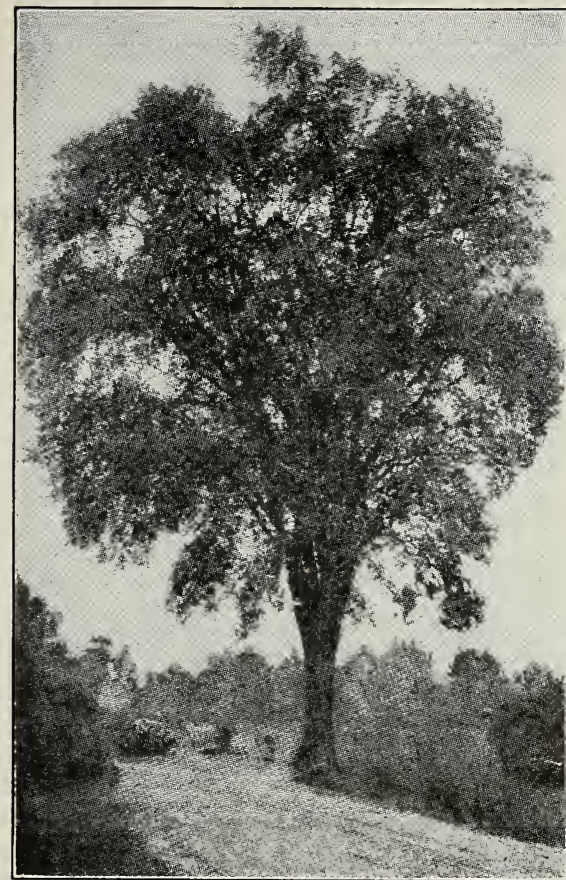

Elm smoke and gas. It makes a spreading head and dense shade when properly trimmed. 8 to $10 \mathrm{ft}$., $40 \mathrm{c}$ each, $\$ 4.00$ per $12 ; 6$ to $8 \mathrm{ft}$., $30 \mathrm{c}$ each, $\$ 3.00$ per $12 ; 5$ to $6 \mathrm{ft} ., 25 \mathrm{c}$ each, $\$ 2.00$ per $12, \$ 15.00$ per 100 ; 4 to $5 \mathrm{ft}$, $20 \mathrm{c}$ each, $\$ 1.80$ per 12 , $\$ 10.00$ per 100 .

Popular Norway-Very much like Carolina. We can furnish them of the same sizes and at the same prices.

Eim--White, the noble, drooping, spreading tree of our woods; one of the grandest of park or street trees. 5 to $6 \mathrm{ft}$., 25 cents each; $\$ 2.40$ per 12 .

Birch, White-A tree with graceful, airy foliage and white bark, desirable for lawns. 5 to 6 ft., 25 cents each.

Mountain Ash-A very pretty, small sized tree, with clusters of large orange berries in the fall. 5 to $6 \mathrm{ft}$., 25 cents each

Mountain Ash (Oak-Leaved)Dark, lobed, oak shaped leaves, downy beneath. Produces berries freely. 5 to $6 \mathrm{ft}$. $35 \mathrm{c}$ each.

Catalpa Specosa-A r a p id grower with large light green leaves and white flowers in June. 6 to $8 \mathrm{ft} ., 35 \mathrm{c}$ each, $\$ 3.60$ per $12 ; 5$ to 6 ft., $25 \mathrm{c}$ each, $\$ 2.40$ per 12 .

Norway Maple-A native of Europe; a large, handsome tree, with broad, deep green, shining foliage, very desirable for street, park or lawns. 5 to $6 \mathrm{ft}$., $40 \mathrm{c}$ each.

Hard Maple-Spreading top and very dense shade, but slow growing. 5 to $6 \mathrm{ft}$., $40 \mathrm{c}$ each.

Tulip Tree (L. Tulipfera) -A tall pyramidal trunk rises to a great height and is clothed with a splendid foliage of large, glossy leaves; large, tulip-shaped flowers are borne in the spring, greenish yellow and orange. One of the most distinguished tall trees. 4 to $5 \mathrm{ft}$., $35 \mathrm{c}$ each.

Linden-American or Basswood (Tili Americana)-A large tree forming a broad, roundtopped crown. Leaves broadly oval, dark green on top and light beneath, turning yellow in au-

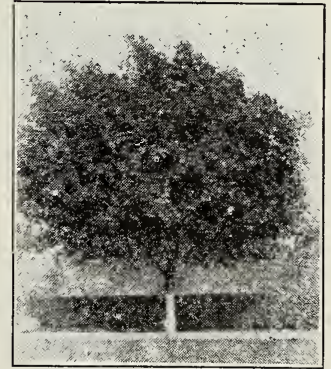

Norway Maple tumn; creamy flowers in summer, and very attractive to the honey bee. A grand tree anywhere. 5 to $6 \mathrm{ft}$., $50 \mathrm{c}$ each. 
Horse Chestnut-White Flowering-A handsome tree of regular form with showy foliage and covered in the spring with panicles of white, showy flowers marked with red. As a lawn or shade tree it has no superior. 4 to $5 \mathrm{ft} ., 50 \mathrm{c}$ each.

Redbud (Cercis)-Judas Tree-A medium sized tree with large irregular head shaped leaves; derives its name; Red Bud, from the profusion of delicate, reddish-pink blossoms with which it is covered in early spring before the foliage appears. One of the finest ornamental trees. 5 to $6 \mathrm{ft}$., $50 \mathrm{c}$.

Oak Pin ( $Q$ Palustris)-A magnificent tree for lawn and street planting. Deep green foliage which changes to a bright scarlet and yellow by autumn; a most shapely and graceful tree, assuming the drooping habit with age. 5 to $6 \mathrm{ft}$., $50 \mathrm{c}$ each.

Willow-Golden-4 to $5 \mathrm{ft}$., $25 \mathrm{c}$ each.

Soft Maple-6 to $8 \mathrm{ft}$., 35c each, $\$ 3.50$ per $12 ; 5$ to $6 \mathrm{ft}$, $25 \mathrm{c}$ each, $\$ 2.00$ per $12, \$ 12.00$ per $100 ; 4$ to $5 \mathrm{ft}$., $20 \mathrm{c}$ each, $\$ 1.80$ per $12, \$ 10.00$ per $100 ; 3$ to 4 ft., $\$ 6.00$ per $100 ; 2$ to $3 \mathrm{ft}$., $\$ 3.00$ per 100 .

Catalpa Seedling $-\$ 1.00$ per $100 ; \$ 4.00$ per 500 . These are the hardy Speciosa. For posts they should be planted $4 \times 4$ feet, and given good cultivation for two or three years. This is very important to get a straight, strong growth. The government report claims they will last as long as red cedar or hedge, and should make good posts in half the time.

\section{WEEPING. TREES}

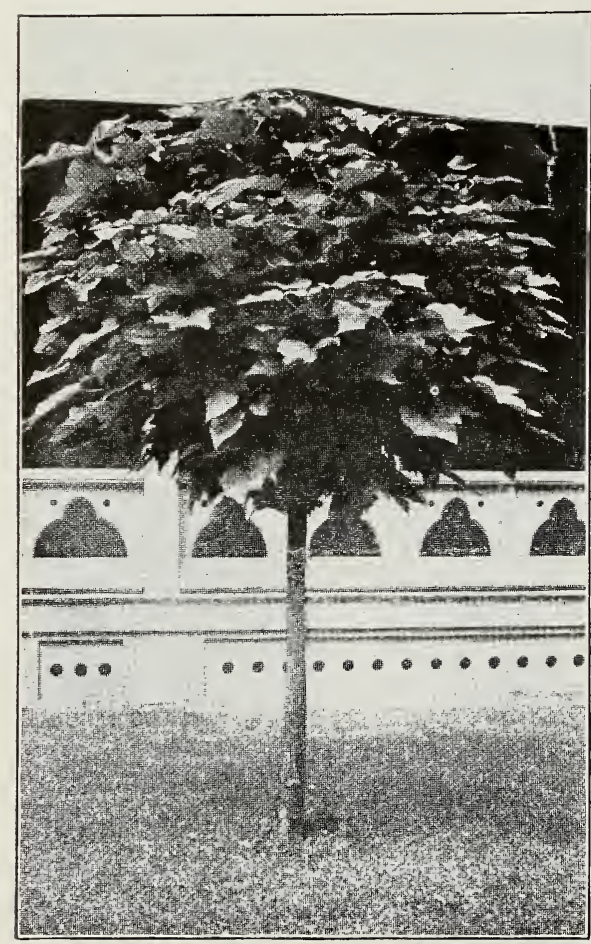

Catalpa Bungeii
Catalpa Bungeii (Umbrella Catalpa)-Grafted on stems six to eight feet high, it makes an umbrella-shaped top with o u t pruning; perfectly hardy; leaves large, glossy, heart-shaped, deep green; lay like shingles on a roof. $\$ 1.00$ each.

Tea's Weeping-A variety of the well known Russian Mulberry. Forms a perfect umbrellashaped head, with long, slender branches which droop to the ground parallel with the stem. Very beautiful and hardy. $\$ 1.00$ each.

\section{WILLOW}

Kilmarnock W e e p ing-An exceedingly graceful tree, very hardy. $75 \mathrm{c}$ each.

Wisconsin Weeping-5 to 6 ft., 40c each.

\section{BIRCH}

Cut Leaved Weeping-Erect, stately, rapid, hardy, with long, fine pendant branches and delicately cut leaves; the trunk very white; no tree more elegant for the lawn or yard. Undoubtedly the most popular of all weeping trees. 5 to $6 \mathrm{ft}$., $\$ 1.00$ each. 


\section{SHRUBS}

Nothing adds so much to the beauty of the home surroundings, nothing gives so much pleasure, as a good lawn and well placed shrubs and vines.

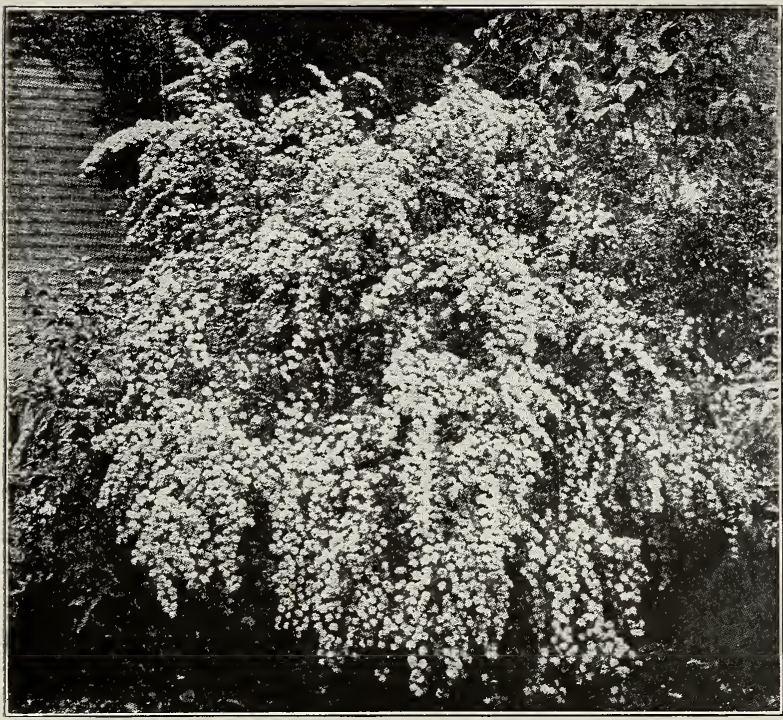

Spirea Van Houtei

The number which may be planted will be governed by the shape and extent of $t$ he grounds, but even the smallest 1 ot has a place for a few. They should be planted in masses, in corners and about the build. ings, always leaving a goodly proportion of open lawn. If you will send us a plat of your grounds and tell us how you would like to have it planted, we will help you select the best plants and assist you in arrang ing them. We will send a blank and instruct ion $s$ for $\mathrm{making}$ a plat u p o n application. Strong two-year

bushes, $25 \mathrm{c}$ each; 6 or more $20 \mathrm{c}$, except where mentioned.

Altheas-A free flowering shrub, blooms in August and September; flowers resemble hollyhocks; color, white and purple.

Almonds-Double flowering, pink and white flowers like small roses, early, profuse.

Barberry (Thunberg's or Japanese)-The finest of all the barberries, grows in compact form, spiney stems, foliage fine and dense, changing to brilliant red in fall, the clusters of red berries hanging on all winter.

Purple Barberry (Vulgaris Purpurea)-Of erect, tall growth, with fine purple foliage; the young shoots are red, and in May it bears small yellow flowers, followed in the fall by bright red fruit.

Buckthorn (Rhamnus cathartica)-A good hedge-plant with dull green foliage; wood black and thorny, with clusters of shiny black berries in autumn and early winter.

Buffalo Berry (Shepherdia argenta)-A low, dense growing perennial shrub with grey or silver foliage, and clusters of small flowers along the stems. Fruit red-yellow, about the size of a pea, produced in abundance. Good for sandy banks. Yellow flowers in June.

Button-bush (Cephalanthus Occidentalis) - A pretty shrub with good foliage and attractive flowers in dense globular heads. White blossoms in July. 35 cents.

Butterfly Bush (Buddleya Variabilis Magnifica)-Ever-blooming. This shrub from a young plant set out in the spring will mature to full size the first summer, making a handsome bush. It produces long, graceful stems, which terminate in tapering panicles of beautiful lilac-colored flowers that are of minature size and borne by the hundreds on a flower head which is 
frequently 10 inches long. A single plant the first season will throw out as many as 50 flower spikes. The year after planting it commences to flower in June and continues until a severe frost. The foliage and blooms are exceedingly fine. In some latitudes this shrub will die down to the ground and while hardy, we recommend covering the roots with leaves or other suitable material as winter approaches, as this will produce a heavy growth the following season. This shrub is very desirable as an individual specimen in the lawn and garden, or placed promiscuously in the shrubbery border. Strong field grown plants, $35 \mathrm{c}$ each, 3 for $\$ 1$; small plants, $20 \mathrm{c}$ each, 6 for $\$ 1.00$.

Calycanthus (Sweet Scented Shrub)-the wood is fragrant, foliage rich; flowers are of chocolate color, having a peculiarly agreeable odor, Flowers in June and at intervals afterwards.

Cranberry (high bush) (Virburnum opulus)-Upright and spreading in growth, with smooth, light grey branches and broad, rough leaves. Flat heads of white flowers about 3 or 4 in. across. The clusters of decorative fruit begin to color by the end of July and remain on the branches and keep their bright scarlet color tuntil the following spring.

Currant (Flowering)-The golden flowering currant, blooms in April and May, followed by large black berries, fragrant and showy, thrives everywhere, in any soil, red leaves in autumn.

DesModium Penduliflorum-A shapely pretty leaved semi-herbaceous shrub from 2 to 4 feet high; literally covered in early autumn with long, drooping racemes of magenta flowers.

Deutzia (Pride of Rochester)-Blooms in early spring, in large panicles of double white flowers. A strong, handsome grower.

Dogwood (Cornus Siberica) - A pretty shrub with bright red bark in winter. Branches upright and spreading. Has cream colored flowers in June, and light blue berries, which makes it very attractive in autumn.

Elder (Golden) - A brilliant golden-leaved variety, very useful for contrasts and striking effects.

Elder (Common)-White flowers borne in large, flat panicles, followed by edible black berries.

Fringe, Purple or Smoktree (Rhus continus)-Good as a single specimen for lawns or in masses in the shrubbery border. Has yellow green flowers in June in loose panicles which become purple and plumose and give the plant a smoky appearance in late summer and early fall. 35 cents.

Fringe White (Chioanthus Virginicia) - White fringe-like fragrant flowers in large, loose racemes in May; ornamental purple fruits in bunches. A useful low tree or shrub. 35 cents.

Golden Bell (Forsythia Suspensa)-Has yellow, bell-shaped flowers in racemes in early spring. Spreading in growth. Good deep green foliage.

Tartarian Honeysuckle (Lonicera Tatarica)-A very attractive, useful shrub, with an abundance of fragrant flowers in the spring, and bright red fruit in autumn. Pink and white.

Hydrangea (Paniculata Grandiflora)-This is one of the most valuable hardy shrubs. It attains a height of three or four feet, and is perfectly hardy in all parts of the country. The flowers are borne in great panicles nearly a foot in length and change from pure white to rose and bronze. It commences flowering in July and continues until November.

Hydrangea (Aberoescens Sterilis, hills of snow)-A new variety of decided merit. Commences to bloom in June and lasts until September. Perfectly hardy. 35 cents.

Hydrangea (Arborescens)-Strong, tall grower with large light green leaves and white flowers in August. 
White Kerria (Rhodotypos Kerrioides)-A very ornamental shrub with bright foliage and single white flowers about one and one-half inches across. In May. These are produced at the end of the branchlets and are followed by conspicuous, shining black fruits in autumn and winter. 35c.

Lilac (Purple) -A standard variety, always good, profuse bloomer.

White-A well known white lilac; flowers slightly cream colored.

Red Lilac-Very much like the purple except the flowers are red.

Lilac Persian-This blooms earlier than the common lilac. The flowers are pale lilac and bend the slender branches in most graceful curves.

Pea Tree (Caragana Siberian)-A showy dwarf tree or shrub with pretty pea-shaped flowers. Grows to a height of about 12 feet and is covered with yellow flowers in May and June.

Pearl Bush (Exochorda Grandiflora)-A very handsome shrub while in bloom. It is open in growth and should be planted back of or massed with other shrubs. Large white flowers in racemes of 4 or 5 . Blooms in May. 35 cents.

Privet (Ligustrum)-Amoors North, Polish, California. Besides being one of our best hedge plants, thry form interesting groops on the lawn. They are almost evergreen of dense compact habit, the flowers are fragrant and are followed by sprays of different colored berries.

Quince Japan (Cydonia Japonica)-One of the most attractive spring flowering shrubs. The scarlet flowers are large and produced in masses. Foliage large, dark, 'glossy green. Good in hedges or for massing in the shrubbery border. Height 5 or 6 feet.

Strawberry Bush (Euonymus Americanus)-A pretty upright growing shrub with good foliage, particularly handsome in fall with its scarlet berries. Excellent for the shrubbery border. Yellow-red flowers in June.

Snowberry-A very pretty bush, with clusters of rose-colored flowers early in the spring, followed by waxy white berries, which hang on through part of the winter. red.

Snowberry (Red Fruited)-Similar to above, except berries are bright

Snowball-A magnificent old favorite, tall growing shrub with very showy pure snow white flowers, produced in large ball.

Snowball (Japan) (Viburnum Pilcatum)-One of the choicest hardy shrubs with healthy dark foliage; the perfect balls of pure white flowers are borne in great profusion in May. 35 cents.

Spirea (golden)-Large white flowers in June, a very strong grower with bright golden leaves in spring, that darken as the season advances.

Spirea (Billardii)-Upright in habit, with red brown branches, dull green foliage and dense spikes of pink flowers about 6 inches long. Blooms from July until frost.

Spirea (Billardii Alba)-A white-fiowering form of the above.

Spirea Van Houtei (Bridal Wreath)-The most beautiful of all spireas, an immense bloomer; pure snow white flowers; early; hardy.

Spirea Anthony Waterer-Dwarf; this beautiful variety produces flowers of bright crimson and blossoms so freely that it may be kept flowering through the summer till late fall by trimming away the dead flowers. In growth it makes a large, round head, one to two feet high.

Sumac (Cut Leaf)-A very striking plant of moderate size, with deeply cut leaves resembling fern leaves, dark green above and glaucous below and turning to a rich red in autumn.

Sumac (Illinois)-Dwarfish; foliage a brilliant glossy green. Small greenish flowers in dense panicles at the end of branches. The crimson fruits and brilliant foliage in autumn give a wonderful wealth of color. 
Syringa (Mock Orange)-Of vigorous habit, very hardy, with large, handsome foliage and beautiful white flowers.

Syringa (Grandiflorus)-Similar to mock orange, except blooms two or three weeks later; blossoms are much larger and without odor.

Tamarisk (African)-A beautiful shrub with feathery asparagus-like foliage, pinkish white blossoms in June and July, decidedly picturesque.

Witch Hazel (Hamamelis Virginiana)-Large yellow flowers which appear in great quantities very late in the autumn. Good among other shrubs and valued because of its late blooming quality. 35 cents.

Weigelia (Diervilla Eva Rathke)-The hardiest of the weigelias; free flowering in June and July. Flowers crimson, very handsome and fragrant. 35 cents.

Yucca-A tropical-looking plant, with long, narrow leaves; the flower stalks rise from the center about three feet high, and are covered with creamy, white bell-shaped flowers, forming a perfect pyramid; perfectly hardy, the leaves staying green all winter. Strong two year plants.

\section{ROSES}

Everblooming Hybrid Perpetuals-Large two year, field grown bushes, 25 cents each, except as noted.

General Jacqueminot-B ri11 i a $\mathrm{nt}$

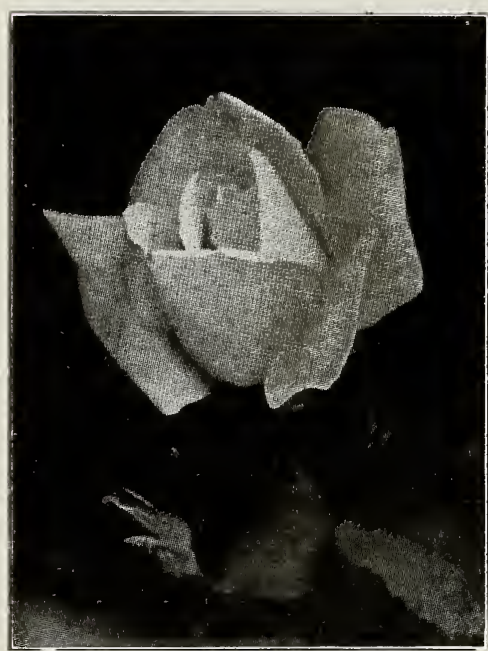

Karl Druschki Rose velvety crimson; large, showy, and a fine grower; a magnificent variety.

Magna Charta-A general favorite, prized on account of its strong, upright growth and bright, healthy foliage, as well as for its magnificent bloom. The color is a beautiful bright pink.

Paul Neyron-Deep, shining rose, very fresh and pretty. Flowers large, often measuring five inches in diameter. The buds always develop fine, perfect roses.

American Beauty-A hardy rose, of the largest size, having the everblooming qualities of the tea roses; it is the sweetest of all roses; the color is a deep, brilliant red, shaded to a rich carmine. 35c each.

Frau Karl Druschki-A pure, paper-white, large sized and free flowering. The bloom is perfect in form, on fine, long stems.

Marshall P. Wilder-The flowers are large and perfect in form, on good length of stems. Desirable for cut flowers, colors bright cherry red, changing to crimson.

Prince de Rohan-Very dark velvety crimson. A prolific bloomer and flowers are of excellent form and size.

Soleil d' Or-A fine hardy out door rose, especially valuable because of its rare color; gold and orange yellow, varying to ruddy gold, suffused with nasturtium red. $35 \mathrm{c}$ each.

Baby Rambler-The original dwarf form of crimson rambler. The wonderful persistency of its bloom makes it one of the choicest plants in cultivation for summer bedding, and as an edging to borders of shrubs, roses or perenials, it has no equal. $30 \mathrm{c} ; \$ 3.00$ per dozen. 
Coquette des Alps-White tinged with pale rose, size medium, fine form; a free bloomer, dainty and attractive.

The above roses are everblooming. They always

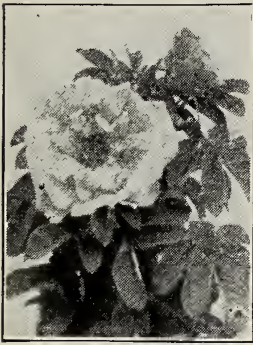

Rugosa bloom on the new growth, and should be cut off eight inches above the ground when planted, and again each fall after the leaves have fallen, and well covered with leaves or grass.

June Roses-Double pink flowers that come out very early in the spring. Very hardy. $15 \mathrm{c}$ each.

Rugosa Rubra-An upright hardy shrub with stout stems. Leaves dark green, large single red flowers followed by ornamental brick red fruit. Blooms from May to September.

Rugosa Alba-Like above except has white flowers.

\section{CLIMBING ROSES}

Large two year field grown vines, 25c each, except where noted.

Climbing American Beauty-Much like the bush form of this name except it has the climbing habit. $35 \mathrm{c}$ each.

Excelsa (Red Dorothy Perkins)-A radiant, blood-red cluster rose. The clusters are very large and fairly cover the vines. It is best to plant this variety where crimson rambler is not hardy.

The Illinois Rose (Rosa Setigera)-Large single, pink, blossoms in July; beautiful foliage, absolutely hardy. The stems turn red in winter which, together with quantities of crimson fruits, produce a charming winter effect.

Crimson Rambler-It is a vigorous grower; flowers glowing crimson and productive in immense panicles.

Flower of Fairfield-Everblooming Crimson Rambler, it blooms on the old wood early and follows up on the new growth until late in the fall. $35 \mathrm{c}$ each.

Blue Rambler (Veilhenblau)-The flowers are a violet blue; the buds show some red, but quickly change as they open.

Dorothy Perkins-Beautiful shell pink, full and double; large size for a cluster rose; it is a hardy, strong grower.

Prairie Queen-The flowers are very large and of peculiar globular form; bright, rosy red, changing to lighter as the flower opens. Of strong, rapid growth.

Baltimore Belle-Pale blush, variegated carmine-rose and white; very double. Flowers in beautiful cluster.

Thousand Beauties (Tausendschon)-Colors of every imaginable shade, from pure white to deep pink. Almost thornless.

\section{CLIMBING VINES}

\section{Strong two year, $25 \mathrm{c}$ each}

Honeysuckle, Scarlet Trumpet-One of the handsomest in cultivation; coral flowers; very vigorous and hardy; blooming all summer.

Honeysuckle, Hall's (Halliana) - A strong grower with deep green foliage, which is almost evergreen. Numerous white and yellow fragrant flowers in August and September.

Trumpet Vine (Tecoma Radicans)-Handsome, dark green foliage and showy clusters of orange and scarlet flowers during the summer. 
Bittersweet-A native vine that is especially ornamental in fall and winter, with brilliant orange and scarlet fruit.

Chinese Matrimony Vine-A strong, hardy climbing vine. Bright, rosy purple flowers, followed by brilliant scarlet berries.

Wisteria (purple)-One of the finest climbers, of rapid growth, and perfectly hardy, with long, pendulous clusters of bluish purple. Flowers in June.

Engleman's Ivy-It is one of the finest ivies we have. The brilliant coloring of the leaves in autumn, together with perfect hardiness, makes it a valuable climber for covering brick or stone walls. Where hardiness is necessary, the Englemani will be found much superior to Boston ivy.

Boston Ivy (Veitchi)-Very much like Engleman's, but rather tender in this climate.

American Ivy--The well known native vine with the five parted leaves, that change to rich crimson in autumn; berries blue black; very rapid

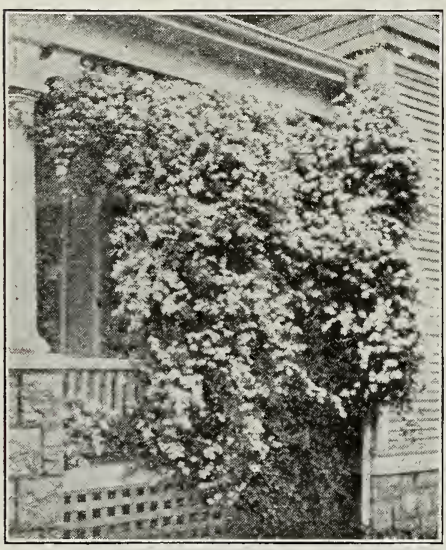

Paniculata grower and perfectly hardy.

\section{CLEMATIS}

\section{2 years}

Jackmanii-A very profuse blooming variety, with flowers from four to six inches in diameter; of an intense violet purple color, borne successionally in continuous masses on the summer shoot. $40 \mathrm{c}$ each.

Henryii-Large, pure white flowering. $40 \mathrm{c}$ each.

Mad Ed Andre-Very much like Jackmanii, except the flowers are crimson red; $40 \mathrm{c}$ each.

Paniculata-New. A strong, vigorous grower; very free flowering; pure white; unusually fragrant. $25 \mathrm{c}$ each.

\section{HEDGES}

American Arbor Vitea-A native of the North; very hardy and easy to transplant and will stand shearing well any time of the year; the most popular for hedges and screens, as it keeps green the year round. 12 to 18 in. transplants, $10 \mathrm{c}$ each, any quantity.

Barberry Thunbergeri-From Japan, of dwarfish habit; small foliage that turns to a scarlet in the fall; small flowers in June that turn to scarlet berries that last through the winter; perfectly hardy; it makes a very pretty hedge. 12 to 18 inches, $10 \mathrm{c}$ each, any quantity.

Privot, Amors-Hardy, a valuable shrub for hedges and borders; foliage glossy green; holds its color almost the whole year. Will stand shearing almost to any extent; very hardy. 12 to 18 inches, 7c each, any quantity.

Spirea Van Houtei-In spring a hedge of Van Houtei is a perfect foundation of pure

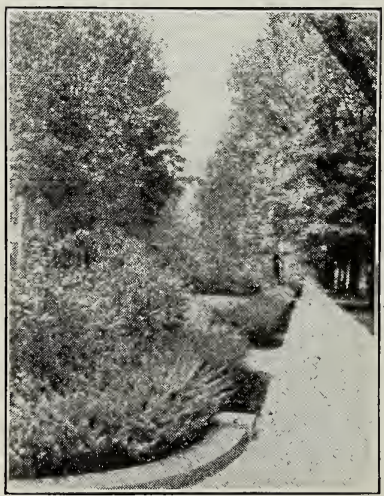

Barberry white bloom. 12 to 18 in., 10 c each.

Hedges should be planted from 12 to 18 inches apart in the row, and kept well cultivated or heavily mulched for a year. 


\section{HARDY PERENNIAL PLANTS}

Baby's Breath (Gypsophila Paniculata)-A most graceful plant, excellent for the border. Numerous small pink flowers in feathery panicles. Useful for cuttings, blooms in June and July. Two ft. high. 25 cents.

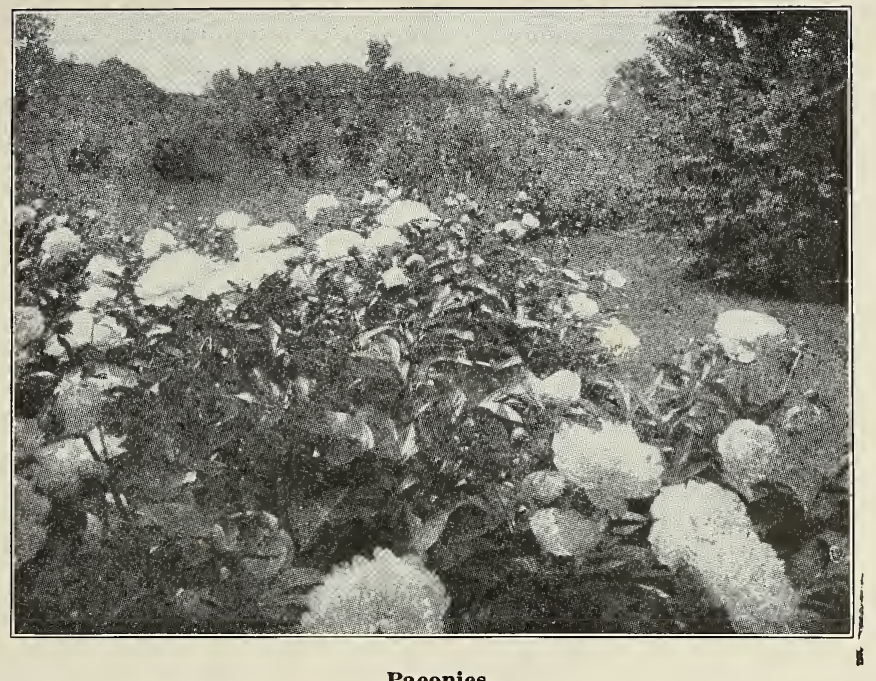

Paeonies

Chrysanthemum (hardy)-They make a brilliant show in September and October. Colors, white, pink and yellow. 15 cents each, 3 for 40 cents.

Fox Glove-A grand display of thimble-shaped flowers in immense spikes during July and August. Separate colors. White and rose. 15 cents, two for $25 \mathrm{c}$.

Golden Rod (Canadian)-The spray of perennial gold terminating with each year's growth, is on stems 3 to 5 feet high. September to October. 15 cents, two for 25 cents.

Golden Glow-Flowers are produced on long stems in large quantities, and resemble golden cactus dalies. 15 cents.

Hibiscus "Meehan's Mallow Marvels"-A magnificent new strain of hardy mallows, which for size and profusion of bloom and richness of coloring are among the most striking and beautiful perennials that grow. Flowers 8 to 10 inches in diameter; color bright red. 25 cents each.

Iris-Blue and yellow mixed. 10 cents each, 12 for $\$ 1.00$.

Larkspur (Hardy)-The long, showy spikes of flowers persist from June till frost and furnish the most satisfactory blues to any color scheme. 20 cents each, 2 for 35 cents.

Lily Day-Yellow. Each 10 cents, 12 for $\$ 1.00$.

Lily of the Valley-Small, white flowers, very fragrant. 5 cents each; 40 cents per 12 .

Lily (Auratum)-Gold-banded Japan lily, considered by many the finest of all hardy lilies. Flowers very large, made up of broad white petals, thickly studed crimson maroon with a bright golden band through he center of each petal. 20c each, $\$ 2.00$ per dozen.

Lily (Candidum) -A pure white garden lily. One of the hardiest. Very fragrant. 15 cents each, $\$ 1.50$ per dozen. 
Lily (Speciosum Melpomene)-Large deep crimson, heavily spotted. 15 cents each, $\$ 1.50$ per dozen.

Lily (Speciosum Rubrum)-White, beautifully spotted with red; flowers in August. 15 cents each, $\$ 1.50$ per dozen.

Paeonies-A gorgeous flower; the dark, green leaves are at all times very attractive; hardy as an oak, and once planted will take care of themselves. Colors, early, red and late, dark red; early, white and late, white; early, pink and late, dark, pink; all double flowers. 25 cents each.

Phlox (hardy)-No class of hardy plants are more desirable than the hardy phlox. They flower from July to late in the fall and are as easy to grow as the paeonies; colors, red, white, pink, salmon, violet with white center and purple. 15 cents each, $\$ 1.50$ per dozen.

Shasta Daisy (Chrysanthemum) Alaska-A creation of Mr. Burbank's which is very free flowering. It succeeds best in deep and somewhat moist soil. Its flowers are daisy-like, often 4 or 5 inches across; color white. 15 cents.

Spirea (Blue, Caryopteris Mastachanthus)-A showy fall flowering plant requiring protection in winter. A pretty plant for the hardy border. Leaves rough and grayish; flowers, lavender, in numerous small clusters along the stem. 25 cents each.

Blazing Star-Dazzling rosy purple spikes. Lasting a long time in July and August. 10 cents each, $\$ 1.00$ per dozen.

\section{CANNAS}

20 cents each, $\$ 2$ per 12.

Beaute Portevine-31/2 ft., large, crimson.

Florence Vaughn-4 ft., golden yellow, dotted red.

Bronze Leaved-3 ft., Vermillion scarlet.

\section{GRASS SEED}

Sudan Grass-25 cents per 1b., 5 to 20 lbs., 20 cents; over 20 1bs., 18 cents. This is for No. 1 new, well cleaned seed. Double drill, 12 lbs. to the acre with broom corn drill, or sew 20 bs. per acre broadcast on a mellow seed bed about May 10. Cut as soon as it commences to head. It will make two or three good cuttings a year of hay as good as timothy. It will make a good crop on light sandy soil.

Blue Grass-25 cents per pound. Sow one pound for three square rods. This is the best lawn grass, sow in April and rake in well.

Black Leaf-1 oz. can, 40 cents, will make 7 gallons spray; one-half $1 \mathrm{~b}$. can, $\$ 1.25$, will make 50 gallons good spray. It is highly recommended for soft bodied sucking insects, and lice on roses. For spraying only. Follow directions on can. 


\section{BULBS FOR FALL PLANTING}

Tulips-Double early, mixed; double late, mixed; single early, mixed; single late, mixed. 35 cents per $12 ; 60$ cents per $25 ; \$ 2.00$ per 100 .

Crocus-Mixed colors, 20 cents per 12;35 cents per 25; \$1.25 per 100. Our mixtures are made up from many large flowering bright colors, which bloom about the same time, and are sure to give good satisfaction. Bulbs should be planted in October. We do not have them for spring planting.

PLANTING-Cut all side limbs back to two or three buds and shorten the top; make the holes plenty large so as not to crowd the roots and plant 3 inches deeper than they grew in the nursery. See that the roots are well spread out; use surface soil for filling, pressing it firmly around them; do not hurry the job; do it well and success is certain. Trees and plants should not long be exposed to the sun and air. Never put manure in the holes next to the roots, it causes decay. Plant strawberries with spade or dibble; spread roots out fan shape.

\section{Proper Distances Between Trees and Plants}

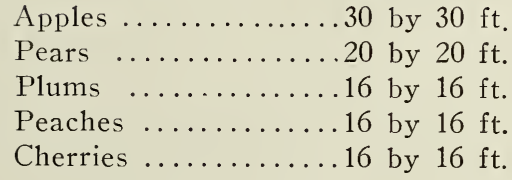

The number of plants required for an acre may be ascertained by dividing the number of square feet in an acre $(43,560)$, by the number of square feet given to each plant.

Urbana, I11., Sept. 10, 1915.

This is to certify that the growing nursery stock and premises of Alpha Nursery, situated at Alpha, Illinois, have been inspected by J. H. Gage, a duly appointed inspector of this office, and that said nursery and premises are apparently free from the San Jose scale and other dangerous insects and dangerous plant disease.

This certificate applies only to the condition of this nursery for the year ending August 24, 1916.
No. 42
S. A. FORBES, State Entomologist. 
